\title{
IMPLEMENTATION OF THE PREVENTIVE VACCINATION PROGRAM AGAINST MEASLES, MUMPS, AND RUBELLA (MMR) ON THE EXAMPLE OF A SELECTED CLINIC IN THE CITY OF KRAKOW
}

Marek Wojczyk ${ }^{1 \mathrm{~A}, \mathrm{~B}, \mathrm{C}, \mathrm{D}, \text { Kinga Cholewa }}{ }^{2 \mathrm{C}, \mathrm{D}, \mathrm{E}, \mathrm{F}}$

${ }^{1}$ Med-All Medical Centre, Krakow, Poland

${ }^{2}$ Whipps Cross University Hospital, United Kingdom

Authors' contribution:

A. Study design/planning • B. Data collection/entry • C. Data analysis/statistics $\bullet$ D. Data interpretation $\bullet$ E. Preparation of manuscript $\bullet$ F. Literature analysis/search $\bullet$ G. Funds collection

\author{
Address for correspondence: \\ Marek Wojczyk \\ Med-All Medical Centre \\ 1 Budziszyńska St. \\ 31-619 Krakow, Poland \\ e-mail: marek.w046@gmail.com \\ SUBMITTED: 20.03 .2020 \\ ACCEPTED: 16.05 .2020 \\ DOl: https://doi.org/10.5114/ppiel.2020.96095
}

\begin{abstract}
Aim of the study: The study aimed to examine the measles-mumps-rubella (MMR) vaccination coverage with the full vaccination schedule (two doses) in children aged 9 and 10 years, and the vaccination rate with the first dose in children aged three years, in the selected Primary Health Care facility.

Material and methods: This is an ecological study, conducted by analysis of medical records. We researched the vaccination coverage of children aged 3, 9, and 10 years in each year between 2010 and 2019 and studied the data of 1610 children. Data were collected from vaccination records and annual vaccination coverage reports. The statistical analysis was done by using the chi-square and Kendall's tau tests.

Results: The percentage of nine-year-olds vaccinated with a second dose of MMR between 2010 and 2019 was $55 \%$ on average $(n=913)$ and $86 \%(n=855)$ in the group of one-year-older children. The number of nine- and 10-year-olds not vaccinated with any single dose of MMR did not increase significantly and oscillated between $0-2 \%$. The average percentage of three-year-olds vaccinated with the first dose of MMR over a 10 -year period was $95 \%(n=1057)$. In 2019 , however, the number of vaccinated children fell below $90 \%$ (86\%), and the number of unvaccinated children more than doubled compared to 2018.

Conclusions: A second dose of MMR vaccine in the studied group is often administered later than recommended in the immunisation schedule. The percentage of vaccinated 10 -year-olds usually does not exceed $90 \%$. There has been an increase in the number of unvaccinated children, mostly three-year-olds.
\end{abstract}

Key words: vaccination, MMR, vaccine calendar.

\section{INTRODUCTION}

Measles is a viral illness transmitted by droplets or airborne with a high infective potential. Swelling of the parotid glands, commonly called mumps, is also caused by the virus and spread by the droplets. Similarly, rubella is a viral illness transmitted by the droplets. Children are the most prone to contract these three different viruses. The long-term complications vary from mild to dangerous or even death [1-3]. The World Health Organisation (WHO) reported that 82,596 people suffered from measles in the European region in 2018 and 72 died [1]. With the aim of preventing the negative health implications, immunisation against the indicated illnesses has been carried out in many countries for years.

In Poland, vaccinations against measles, mumps, and rubella have been compulsory since 2004 [4]. For this purpose, a combination vaccine called MMR (measles-mumps-rubella) is used. The immunisation schedule requires a child to receive two doses of MMR. Children should be vaccinated with the first dose once they are between 13 and 14 months old. This is to be followed by a second dose (booster) when they are 10 years old [5].

In 2019 the National Institute of Public Health in Poland published data about childhood vaccination coverage in the previous year-2018. A drop in the number of two-year-old children vaccinated with the MMR was observed between 2009 and 2018 on a nationwide scale. The vaccination coverage was $84 \%$ in 2009 but only $74 \%$ in 2018 . Across the whole group of 10 -yearolds (born 2009) about $73.9 \%$ received the second dose of MMR in 2018, and among 11-year-olds (born 2008) it was $92.4 \%$ [6].

In the Małopolskie voivodeship, MMR vaccine coverage was $91.2 \%$ in children aged three years. 
In comparison, diphtheria and tetanus vaccination coverage among three-year-olds was $96.8 \%$ in 2018 , meaning $3.2 \%$ of them were not vaccinated [6].

Due to an increase in the number of measles outbreaks in Europe, new guidelines were introduced in 2019, and the second dose is now to be administered when children are six years old. It is believed to provide higher immunity against measles, mumps, and rubella $[1,5]$.

The anti-vaccination movements have a significant impact on social perception of vaccines and might be responsible for influencing parents' decision about vaccinations [2].

Due to the article written by A. Wakefield in 1998, the MMR vaccine was associated with a higher occurrence of inflammatory bowel disease and autism. Although Wakefield's paper has been discredited by a great deal of scientific evidence, parents' concerns about the $M M R$ vaccine are still ongoing $[1,2,7]$ Other potential causes of negative attitudes towards vaccination leading to rejection of them include low health literacy, limited trust in the health system, and belief in the Big Pharma conspiracy theory [8].

\section{AIM OF THE STUDY}

The aim of the study was to examine the MMR vaccination coverage with the full vaccination schedule (two doses) in children aged 9 and 10 years as well as the vaccination rate with the first dose in children aged three years in the selected Primary Health Care facility.

\section{MATERIAL AND METHODS}

The study was conducted in the Med-All Medical Centre in Krakow, which provides primary health care including a paediatric outpatient clinic. Most of the children under the care of practice were residents of Krakow (98.7\%).

This is an ecological study that belongs to the group of analytical observational studies. It was conducted by analysing medical records. Overall, the data of 1610 children born between 2000 and 2016 were analysed. The data were collected from 392 vaccination records of children born in 2016, 2010, and 2009, who were 3, 9, or 10 years old, respectively, in 2019. All other data of children born in 2000-2008 and 2011-2015 were collected from annual vaccination coverage reports.

The data were analysed over the 10-year period from 2010 to 2019. Children under the age of six years, who were vaccinated with the second dose of MMR in 2019, were not included in the sample group due to the lack of a reference point to previous years. However, children under the age of 11 years (but over 10 years old) were included in the sample group due to the nu- merous missed vaccinations in children who were subject to vaccination in a given year. In addition, the number of three-year-olds vaccinated with a single dose of $M M R$ vaccine was analysed. This vaccination should have taken place between the age of 13 and 14 months.

The analysis was carried out and the results were developed in MS Excel (Microsoft) and R statistical package version 3.3.2.

The chi-square test was used to check the significance of differences in the number of children vaccinated with the full vaccination schedule (two doses) at the age of nine and 10 years. The correlation between the number of three-year-olds vaccinated with the first dose and individual years was tested using Kendall's tau test. The level of statistical significance was $p<0.05$.

\section{RESULTS}

The analysis of the MMR vaccine coverage in the researched group was divided into two parts. First, the situation of older children who were subject to the mandatory second dose is presented (Table 1, Figure 1), followed by children aged three years, who should have been vaccinated with the first dose (Table 2, Figure 2).

The percentage of nine-year-olds vaccinated with the second dose of MMR over the 10-year period (2010-2019) was $55 \%$ on average $(n=913)$. The lowest percentage of children vaccinated with the second dose (< 45\%) occurred in 2016 and 2017. The highest level of coverage among nine-year-olds was observed in 2012; however, it did not exceed 70\% (69.23\%).

The average percentage of vaccination coverage in the group of 10 -year-olds was $86 \%$ over the 10 -year period $(n=855)$ (Table 1$)$, and in the five analysed years it exceeded $90 \%$. However, the vaccination coverage was not greater than $95 \%$, which is the herd immunity threshold [1].

The lowest level of vaccinated 10-year-olds was recorded in 2010 and 2011 (75\%).

The number of 9 and 10-year olds not vaccinated with any single dose of MMR did not increase significantly and oscillated between 0 and $2 \%$ during the analysed 10-year period.

At the age of 10 years there were still children with only one dose of MMR vaccine, but it is not possible to identify clear statistical trends (Figure 1).

Aggregating data in the form of summing up the observations for all the analysed years in terms of the nine- and 10-year-olds vaccinated with two doses of $M M R$ allows us to state that the MMR vaccine coverage in the researched groups of nine- and 10-yearolds depends on age $(p<0.001)$ (Table 2$)$.

The number of fully vaccinated 10 -year-olds is therefore statistically significantly higher than the number of fully vaccinated nine-year-olds (Table 3). 
Table 1. Nine- and 10-year-olds vaccinated with MMR from 2010 to 2019

\begin{tabular}{ccccccccc}
\hline Year & \multicolumn{9}{c}{ 9-year-olds } & \multicolumn{5}{c}{10 -year-olds } \\
\cline { 2 - 9 } & $\begin{array}{c}\text { Unvaccinated } \\
n(\%)\end{array}$ & $\begin{array}{c}1 \text { dose } \\
n(\%)\end{array}$ & $\begin{array}{c}2 \text { doses } \\
n(\%)\end{array}$ & $\begin{array}{c}\text { Total } \\
(n)\end{array}$ & $\begin{array}{c}\text { Unvaccinated } \\
n(\%)\end{array}$ & $\begin{array}{c}1 \text { dose } \\
n(\%)\end{array}$ & $\begin{array}{c}2 \text { doses } \\
n(\%)\end{array}$ & $\begin{array}{c}\text { Total } \\
(n)\end{array}$ \\
\hline 2010 & $3(4.11)$ & $23(31.51)$ & $47(64.38)$ & 73 & $0(0)$ & $16(25)$ & $48(75)$ & 64 \\
\hline 2011 & $1(1.32)$ & $38(50)$ & $37(48.68)$ & 76 & $0(0)$ & $17(24.64)$ & $52(75.36)$ & 69 \\
\hline 2012 & $0(0)$ & $28(30.77)$ & $63(69.23)$ & 91 & $0(0)$ & $7(9.59)$ & $66(90.41)$ & 73 \\
\hline 2013 & $1(1.25)$ & $30(37.5)$ & $49(61.25)$ & 80 & $0(0)$ & $7(7.69)$ & $84(92.31)$ & 91 \\
\hline 2014 & $0(0)$ & $24(32.43)$ & $50(67.57)$ & 74 & $0(0)$ & $8(9.64)$ & $75(90.36)$ & 83 \\
\hline 2015 & $1(1.05)$ & $45(47.37)$ & $49(51.58)$ & 95 & $0(0)$ & $7(9.09)$ & $70(90.91)$ & 77 \\
\hline 2016 & $1(0.96)$ & $66(63.46)$ & $37(35.58)$ & 104 & $1(1.06)$ & $9(9.57)$ & $84(89.36)$ & 94 \\
\hline 2017 & $1(1)$ & $57(57)$ & $42(42)$ & 100 & $1(0.97)$ & $15(14.56)$ & $87(84.47)$ & 103 \\
\hline 2018 & $2(1.85)$ & $56(51.85)$ & $50(46.3)$ & 108 & $0(0)$ & $9(9.47)$ & $86(90.53)$ & 95 \\
\hline 2019 & $2(1.79)$ & $39(34.82)$ & $71(63.39)$ & 112 & $2(1.89)$ & $17(16.04)$ & $87(82.08)$ & 106 \\
\hline
\end{tabular}

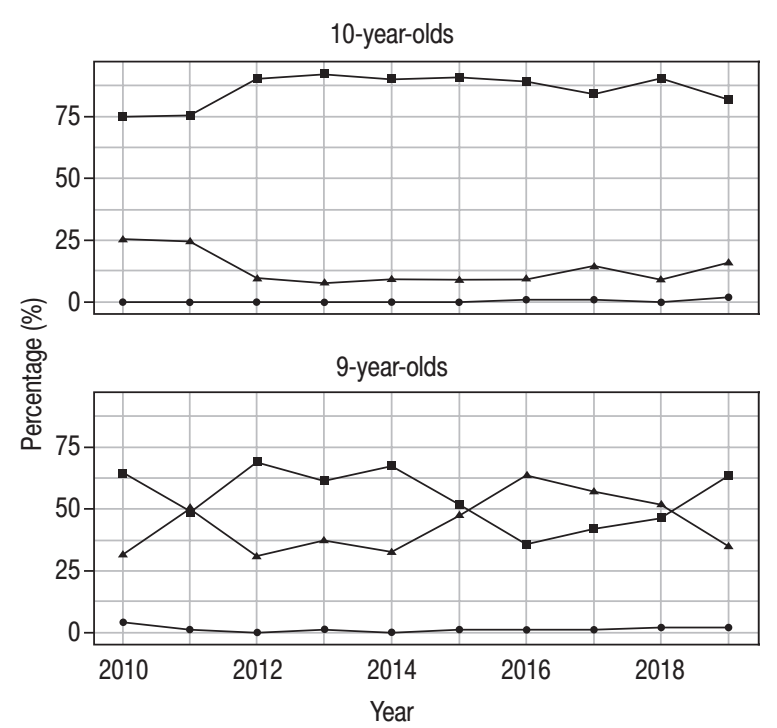

dose $0,1: 2$

Figure 1. Trends in MMR vaccination coverage of 9 - and 10-yearolds from 2010 to 2019

Table 3. Basic MMR vaccination in 3-year-olds from 2010 to 2019

\begin{tabular}{lccc}
\hline $\begin{array}{l}\text { Age } \\
\text { (years) }\end{array}$ & $\begin{array}{c}\text { Uncompleted } \\
\text { vaccination } \\
n(\%)\end{array}$ & $\begin{array}{c}\text { Completed } \\
\text { vaccination } \\
n(\%)\end{array}$ & $\begin{array}{c}\text { Total } \\
(n)\end{array}$ \\
\hline 2010 & $1(1.18)$ & $84(98.82)$ & 85 \\
\hline 2011 & $0(0)$ & $77(100)$ & 77 \\
\hline 2012 & $2(2.44)$ & $80(97.56)$ & 82 \\
\hline 2013 & $3(2.21)$ & $133(97.79)$ & 136 \\
\hline 2014 & $5(5.68)$ & $83(94.32)$ & 88 \\
\hline 2015 & $6(4.88)$ & $117(95.12)$ & 123 \\
\hline 2016 & $8(5.93)$ & $127(94.07)$ & 135 \\
\hline 2017 & $6(5.88)$ & $96(94.12)$ & 102 \\
\hline 2018 & $7(6.48)$ & $101(93.52)$ & 108 \\
\hline 2019 & $17(14.05)$ & $104(85.95)$ & 121 \\
\hline
\end{tabular}

Table 2. Results of chi-square test after aggregating data of 9- and 10-year-olds (completed and uncompleted vaccination)

\begin{tabular}{lccc}
\hline $\begin{array}{l}\text { Age } \\
\text { (years) }\end{array}$ & $\begin{array}{c}\text { Uncompleted } \\
\text { vaccination } \\
n(\%)\end{array}$ & $\begin{array}{c}\text { Completed } \\
\text { vaccination } \\
n(\%)\end{array}$ & $\begin{array}{c}\text { Total } \\
(n)\end{array}$ \\
\hline 9 & $418(45.78)$ & $495(54.22)$ & 913 \\
\hline 10 & $116(13.57)$ & $739(86.43)$ & 855 \\
\hline & $\chi^{2}=215.85, \mathrm{df}=1, p<0.001$ & \\
\hline
\end{tabular}

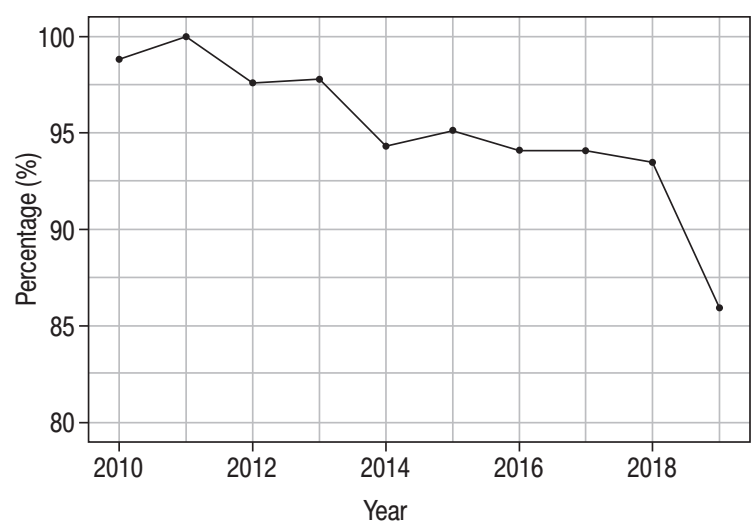

Figure 2. Trends in MMR vaccination in 3-year-olds from 2010 to 2019

The average percentage of three-year-olds vaccinated with the first dose of MMR over the 10-year period was $95 \%(n=1057)$. However, in 2019 , the number of vaccinated children fell below $90 \%$ (86\%), which means the number of unvaccinated children more than doubled compared to 2018 (Figure 2). In the previous years, vaccination coverage with the first dose exceeded $90 \%$.

Furthermore, a 10-year analysis of children under the care of the selected clinic indicates a decrease in the number of three-year-olds vaccinated with the first dose of MMR. Kendall's tau test proves the existence of a strong monotonic relationship between the 
number of vaccinated children and the year of vaccination $(r=-0.822, p<0.001)$.

In summary, there is a systematic increase in the number of children unvaccinated with the first dose in the researched clinic.

\section{DISCUSSION}

An important factor to consider is herd immunity, which is established when the level of vaccination coverage in the population is above $95 \%$. People who are not vaccinated for various reasons and those who, despite vaccination, have not developed longterm immunity to the pathogens in question will still be protected due to the limited transmission of microorganisms in such a population $[3,9,10]$. Lasting resistance to measles, mumps, and rubella will be achieved after being vaccinated with two doses. Despite the Global Vaccine Action Plan (GVAP) implemented by the WHO, an increased incidence of measles was registered in 2018 [1].

The nationwide vaccination coverage with two doses of MMR vaccine according to the immunisation schedule stands at $73.9 \%$ for nine-year-olds and $92.4 \%$ for 10 -year-olds. However, in the Małopolskie voivodeship the rates are $73.8 \%$ for children aged nine years and $91.5 \%$ for 10 -year-olds (data obtained in 2018) [6]. The significant differences in the percentages of vaccinated children between both age groups are the result of the fact that parents often do not vaccinate their children in the scheduled year but postpone the vaccination appointment.

As a comparison, the childhood vaccination coverage in the United Kingdom in 2018, was 94.5\% for the first dose of MMR and $86.4 \%$ for the second one. The 10-year trend in 2008-2018 indicates an increase in vaccine coverage for the second dose of MMR in the British population despite a slight decrease in the years 2016 to 2018 (88\% in 2016 and 86.4\% in 2018) [11].

The data for Greater London were lower than in the other parts of the country. Only $76.3 \%$ of Londoners received a second dose of MMR vaccine [11].

In the above study, the level of vaccination coverage with the second dose of MMR among nine-yearold patients in the selected Primary Health Care facility in Krakow is also lower (46.3\%) than in the whole country $(73.9 \%)$ or in the region $(73.8 \%)$.

The situation improves in the group of children a year older (10-year-olds). The vaccination coverage was $92.4 \%$ nationwide, $91.5 \%$ in the Małopolskie voivodeship, and $90.53 \%$ in the studied population in the selected Primary Health Care facility [6]. Nevertheless, patients in the researched population have lower vaccination coverage in comparison to national or regional levels.

In regard to vaccination coverage with the first dose of MMR vaccine in children aged three years, the nationwide coverage in 2018 was $96 \%$ and $95.4 \%$ in the Małopolskie voivodeship [6]. In the studied population, the percentage of children receiving the first dose of the MMR vaccine was $93.5 \%$. The level of vaccination coverage in the Polish population is therefore higher than in the studied population.

Despite, a nine-year trend of vaccination coverage with the first dose of MMR vaccine above $90 \%$, a twofold increase $(14.5 \%)$ in the number of unvaccinated three-year-old children was observed in 2019 (Table 2). Over the last 10 years, there has been a growth in the number of children not receiving any dose of the MMR vaccine in the studied population (Figure 2) as well as in the national population [6]. The consequence of decreased coverage with the MMR vaccine is an increase in the incidence rate of the measles, mumps, and rubella [1].

There was a three-fold increase in the incidence of measles, which mainly affected unvaccinated persons in Poland in 2016 [12, 13], while in 2017 a twofold decrease was observed, but in 2018 another rise in measles cases was recorded [14]. According to a study conducted by Korczyńska and Rogalska, over 2000 cases of mumps were registered in 2014, and the majority of the sick children were not vaccinated or had only one dose of vaccine [15]. According to Sun et al., children vaccinated with only one dose of MMR vaccine were still at risk of viral infection in comparison to children immunised with the two doses of MMR vaccine [16]. Therefore, it is important to monitor childhood vaccination coverage and to educate parents on the necessity of receiving a second dose of MMR vaccine.

The reasons why parents do not report to a clinic to vaccinate their children with the MMR vaccine are commonly not documented in vaccination records; therefore, they were not identified in the studied population.

Dońka et al. state that apart from a lack of trust for healthcare workers, the other reasons behind rejection of vaccinations include religious and personal believes, uncertainty regarding vaccine safety, and the sense of a lack of information [8]. Słopiecka and Kwiecień point out that mass media, information chaos, and celebrities promoting a natural lifestyle and avoidance of vaccinations negatively influence people's attitude towards vaccination [17].

According to Kochman and Rudzińska, inadequate health education of parents is a major factor for their decision to not vaccinate their children. Researchers prove that a thorough education translates into more vaccinated children. In the institutions where extensive health education is provided, the percentage of vaccinated children exceeded the level of those vaccinated in the national population [18]. Information obtained from medical staff has the greatest impact on changing a parent's decision about vaccinations, 
according to the research by Gańczyk et al. [19]. The style of communication also has a significant impact on parents' perception of vaccinations [2]. It seems, therefore, that it is necessary to conduct longterm educational activities about vaccinations in order to increase the number of vaccinated children and thus obtain the aforementioned herd immunity.

\section{CONCLUSIONS}

A relatively low percentage $(60 \%)$ of children in a given year received the compulsory second dose of $M M R$ vaccine in the researched clinic. A second dose is therefore often given later than it should be.

The percentage of vaccinated 10-year-olds in the studied population rarely exceeded $90 \%$.

In 2019, there was a sudden rise in the number of three-year-olds failing to receive the MMR vaccine in the researched population. This trend can be a part of an increasing nationwide trend in the number of unvaccinated children.

Due to the increase in the number of unvaccinated children, there is a need to raise awareness among parents about the necessity of vaccinations.

\section{Disclosure}

The authors declare no conflict of interest.

\section{References}

1. Nowicka PM, Izdebski R, Kitowska W, et al. Review of measles-related events recorded by the National IHR Focal Point in Poland in the years 2016-2018. Przegl Epidemiol 2019; 73: 3-18.

2. Su SB, Chang HL, Chen AK. Current status of mumps virus infection: epidemiology, pathogenesis, and vaccine. Int J Environ Res Public Health 2020; 17: 1686.

3. Eriksen J, Davidkin I, Kafatos G, et al. Seroepidemiology of mumps in Europe (1996-2008): why do outbreaks occur in highly vaccinated populations? Epidemiol Infect 2013; 141: 651-666.

4. Program Szczepień Ochronnych na rok 2004. http://www. czytelniamedyczna.pl/2133,program-szczepieN-ochronnych -na-rok-2004.html (accessed: 2.02.2020)

5. Program Szczepień Ochronnych na rok 2019 https://gis.gov.pl/ wpcontent/uploads/2018/01/akt.pdf (accessed: 2.02.2020).

6. Narodowy Instytut Zdrowia Publicznego PZH, Główny Inspektorat Sanitarny. Szczepienia Ochronne w Polsce w 2018 roku. Warszawa 2019. http://wwwold.pzh.gov.pl/ oldpage/epimeld/2018/Sz_2018.pdf (accessed: 9.04.2020).

7. Mrożek-Budzyn D, Kiełtyka A, Majewska R. Brak związku między szczepieniami skojarzoną szczepionką przeciw odrze, śwince i różyczce (MMR) a występowaniem autyzmu u dzieci - wyniki badania kliniczno-kontrolnego. Przegl Epidemiol 2009; 63: 107-112.

8. Dońka K, Suwała M, Zarzycka D, et al. Postawy i edukacja wakcynologiczna rodziców. Pielęgniarstwo XXI wieku 2018; 17: 58-64.

9. Barrett ADT, Hawkins BE. Vaccines from a global perspective. In: Milligan GN, Barrett ADT (eds.). Vaccinology: an essential guide. Wiley-Blackwell, Chichester 2015; 319-334.
10. Beverley P. Immunology of vaccination. Br Med Bull 2002; 62: $15-28$.

11. NHS Digital, Childhood Vaccination Coverage Statistics England 2017-18. Published 18 September 2018. https://files. digital.nhs.uk/55/D9C4C2/child-vacc-stat-eng-2017-18-report. pdf (accessed: 12.04.2020).

12. Bogusz J, Paradowska-Stankiewicz I. Measles in Poland in 2016. Epidemiol Rev 2018; 72: 267-274.

13. National Institute of Public Health - National Institute of Hygiene, Chief Sanitary Inspectorate Infectious diseases and poisonings in Poland in 2017. http://wwwold.pzh.gov.pl/ oldpage/epimeld/2017/Ch_2017.pdf (accessed: 23.01.2020).

14. National Institute of Public Health - National Institute of Hygiene, Chief Sanitary Inspectorate. Cases of selected infectious diseases in Poland from January 1st to December 31st, 2018 and in the analogous period of 2017. http://wwwold. pzh.gov.pl/oldpage/epimeld/2018/INF_18_12B.pdf (accessed: 29.01.2020).

15. Korczyńska MR, Rogalska J. Mumps in Poland in 2014. Przegl Epidemiol 2016; 70: 183-187.

16. Sun X, Tang F, Hu Y, et al. High risk of mumps infection in children who received one dose of mumps-containing vaccine: waning immunity to mumps in children aged 2-5 years from kindergartens in Jiangsu Province, China. Hum Vaccin Immunother 2020; 24: 1-5.

17. Słopiecka A, Kwiecień E. Przyczyny negatywnych postaw ludności wobec szczepień. Reasons for the public's negative attitude towards vaccination. Hygeia Public Health 2014; 49: 685-689.

18. Kochman D, Rudzińska T. Znaczenie edukacji rodziców w kontekście szczepień obowiązkowych i zalecanych u dzieci w wieku 0-2 lat. Probl Pieleg 2008; 1: 163-172.

19. Gańczak M, Dmytrzyk-Daniłów G, Karakiewicz B, et al. Determinants influencing self-paid vaccination coverage, in 0-5 years old Polish children. Vaccine 2013; 31: 5687-5692. 